\title{
Assessment of Critical Knowledge on Maternal and Newborn care Services among Primary Level Nurse Mid-wives in Kapilvastu District of Nepal Acharya $\mathrm{D},{ }^{1}$ Paudel $\mathrm{R}^{2}$
}

\author{
${ }^{1}$ Department of Public Health \\ Sanjeevani College of Medical Science \\ Purbanchal University \\ Butwal, Rupandehi, Nepal. \\ ${ }^{2}$ Department of Community Medicine and Public \\ Health \\ Institute of Medicine, Tribhuwan University. \\ Kathmandu, Nepal.
}

\section{Corresponding Author}

Dilaram Acharya

Department of Public Health

Sanjeevani College of Medical Science

Purbanchal University

Butwal, Rupandehi, Nepal.

E-mail: dilaramacharya123@gmail.com

Citation

Acharya D, Paudel R. Assessment of Critical Knowledge on Maternal and Newborn care Services among Primary Level Nurse Mid-wives in Kapilvastu District of Nepal. Kathmandu Univ Med J 2015;52(4):351-6.

\section{ABSTRACT}

\section{Background}

Despite greater emphasis on maternal and neonatal health through policy and programming in Nepal, maternal and neonatal health is still not impressive. Health care providers' knowledge assessment on maternal and neonatal care has been well documented elsewhere, but it is very little understood in Nepal.

\section{Objective}

The primary objective of this study was to assess the critical knowledge of primary level nurse- midwives on maternal and newborn care in Kapilvastu District of Nepal.

\section{Method}

This was an Institution based cross-sectional study, conducted in Kapilvastu district, Nepal among sixty eight nurse-midwives. The participants were selected using simple random sampling technique. For collecting the data, health institutions were visited by enumerators for a month from $1^{\text {st }}$ October to $1^{\text {st }}$ November 2012 . Data were entered into Microsoft Excel, cleaned and analyzed using SPSS version 17.0.

Result

More than $3 / 4^{\text {th }}$ of the nurse-midwives had $10-20$ years of experience. Majority of them (89.7\%) had poor knowledge in taking action to prevent mother to child transmission for HIV positive women. More than half of them $(54.4 \%)$ had some knowledge in performing the active management of third stage of labor whereas almost half $(51.5 \%)$ had poor knowledge to actions needed on post-partum haemorrhage (PPH). Similarly, more than two third (69.1\%) had poor knowledge in newborn care.

\section{Conclusion}

Majority of the nurse-midwives were found to have either poor or some level of knowledge in most of the components of maternal and newborn care services. So, greater emphasis should be given to upgrade the knowledge of nurse mid-wives.

\section{KEY WORDS}

Knowledge, maternal and newborn care services, nurse mid-wives 


\section{INTRODUCTION}

Improving health of mothers and children can contribute to the health of general population. ${ }^{1}$ However, globally; eight million women suffer from pregnancy related complications of which approximately $80 \%$ of maternal deaths are due to direct obstetric complications and only $62 \%$ of childbirths are assisted by qualified health personnel in developing countries. $^{2-4}$

Nepal has high maternal deaths (229/100000 live births) and major causes include pregnancy-related complications, lack of skilled birth attendants and absence of emergency services. ${ }^{5,6}$ Similarly, neonatal deaths in Nepal is still high (23/1000 live births) suggesting the continuous threat to child survival. ${ }^{7}$ Competent nurse practitioners and skilled delivery care within health care system is crucial to ensure quality health services for saving lives of mothers and newborns. ${ }^{7,8}$ However, still low coverage of skilled birth attendants (55.6\%) and institutional delivery (55.2\%) indicating poor health care markers in Nepal. ${ }^{7}$

Although health care providers' knowledge is essential for improving the maternal and newborn health, there have been a wide gap in recommended knowledge of maternity health services among them in developing countries. ${ }^{9}$ Nigerian studies identified reduced knowledge of active management of third stage of labor among maternity health care providors. ${ }^{10,11}$

Despite safe motherhood and neonatal health programme is a focused health programmes of Nepal, this initiative yet to be evaluated. ${ }^{12}$ So, this research was conducted to assess the critical knowledge of maternal and newborn care among nursing personnel working under primary level health care facilities in Kapilvastu District of Nepal.

\section{METHODS}

An institution-based descriptive cross-sectional research design was applied in this study. A total of 68 Upgraded Auxillary Nurse Mid-wives (UANMs), Auxillary Nurse Midwives (ANMs) and Senior Auxillary Nurse-midwives(SANMs) of various health institutions of primary level health care of the same District constituted the sample size of the study.

In Nepal, maternal and child health care in rural areas is usually provided by ANMs who have had at least 18 months training after their $10^{\text {th }}$ grade of education and they are upgraded as SANMs with eight years of regular working experience in public health facility of Nepal. UANMs are upgraded position of MCHWs after their 18 months of training of ANM course. MCHW has three months training on some components of maternal and child health after $8^{\text {th }}$ grade of education. As per the national health policy of Nepal, all health care workers working below the district health office or district public health office such as primary health care centre (PHCC), health post (HP) and sub- health post (SHP) are known as primary level health care providers. ${ }^{13-15}$

All three Primary Health Care Centers (PHCCs) and seven Health Posts (HPs) were included for the study whereas only $50 \%$ of the Sub Health Posts (SHPs) were randomly selected out of 77. From the selected health institutions all nurse midwives i.e. 50 UANMs and 18 ANMs/SANMS were included in the study. For collecting the data, health institutions were visited by enumerators for a month from $1^{\text {st }}$ October to $1^{\text {st }}$ November 2012 and interviewed the participants using structured interview schedule. The interview schedule consisted of two parts: 1) personal profile of the respondents, and ii) knowledge of maternal and newborn care on some selected components of maternity and newborn care. This study was approved by the research committee of Sanjeevani College of Medical Science, Purbanchal University, Butwal. Permission letter was obtained from District Health Office (DHO) Kapilvastu prior to the study. A written Informed consent was taken from each of the respondents before data collection. In a total of 77 respondents, nine were not available during data collection. Personal identification of the respondents were removed before data analysis.

Components of critical knowledge of maternal and newborn care services used in the study were- actions taken to prevent/reduce MTCT for HIV positive women, key steps of performing active management of third stage of labor, actions needed on post-partum haemorrhage (PPH) due to atonic uterus, equipment and supplies needed for immediate newborn care, care needed to newborn with no complication and sign and symptoms of severe infection in newborn. Each component consisted of number correct options. Each correct option of each component was given one point. If correct answers were less than or equal to $33 \%$ of the total score of individual component, these respondents were considered poor level of knowledge (poor knowledge). If they get more than 33\% to less than or equal to $66 \%$ of the score, the respondents were considered some level of knowledge (some knowledge) and good level of knowledge (good knowledge), if they get more than $66 \%$ of the score. Data were entered into Microsoft Excel, cleaned and analyzed using SPSS version 17.0.

\section{RESULTS}

Nearly half of the respondents (45.7\%) were of $30-40$ years of age group followed by $38.2 \%$ in the age group $40-50$ years. Almost all of them were married (97.1\%). Majority of them were UANMs (64.7\%) followed by $25 \%$ SANMs and $10.3 \%$ ANMs. Two third of mid-wives (66.2\%) had technical education as $\mathrm{MCHW}$ and rest had ANM. More than $3 / 4^{\text {th }}$ of them (79.4\%) were having $10-20$ years of experience followed by $13.4 \%$ having $>20$ years of experience and rest were $<10$ years of experience.(Table 1 ). 
Table 1. Personal Profile of the study population ( $N=68$ )

\begin{tabular}{|lcl|}
\hline Characteristics & Frequency & $\%$ \\
\hline Age of the respondent (years) & & \\
\hline $20-30$ & 6 & 8.9 \\
\hline $30-40$ & 31 & 45.7 \\
\hline $40-50$ & 26 & 38.2 \\
\hline$>50$ & 5 & 7.2 \\
\hline Marital status of respondents & & \\
\hline Married & 66 & 97.1 \\
\hline Unmarried & 2 & 2.9 \\
\hline Designation of the respondents & \\
\hline SANM & 17 & 25.0 \\
\hline ANM & 7 & 10.3 \\
\hline UANM & 44 & 64.7 \\
\hline Technical Education of the respondents & \\
\hline ANM & 24 & 34.3 \\
\hline MCHW & 44 & 66.7 \\
\hline Respondents by experience(years) & 7.2 \\
\hline$<10$ & 5 & \\
\hline $10-20$ & 54.4 \\
\hline$>20$ & 9 & \\
\hline & & \\
\hline
\end{tabular}

Over all knowledge of respondents on maternal and newborn care services is presented in table 2. Respondents having had poor knowledge in taking action to prevent/ reduce MTCT for HIV positive women (89.7\%), performing the active management of third stage of labor and lifesaving skills (38.3\%), actions needed on PPH due to atonic uterus (51.5\%), in equipment and supplies needed for immediate newborn care (80.9\%), care needed to newborn with no complication (69.1\%), sign and symptoms of severe infection in newborn (55.9\%)

Respondents' knowledge by designation has been demonstrated in table 3. Poor knowledge on action taken to PMTCT among UANMs (95.5\%), SANMs (82.4\%) and ANMs (71.4\%). Majority of nursing staffs had some knowledge on active management of IIIrd stage of labor and life-saving skills and very few ANMs (28.6\%) and SANMs $(17.6 \%)$ had good knowledge of the same. More than half of the respondents had poor knowledge on action needed for heavy bleeding and only $5.9 \%$ of SANMs and $14.3 \%$ ANMs had good knowledge. Most of the nursing staffs (UANMs-93.2\%, ANMs-85.7\% and SANMs-70.6\%) had poor knowledge on equipment needed to immediate newborn care whereas only $5.9 \%$ of SANMs had good knowledge. Most of the UANMs had poor knowledge on newborn care (90.9\%) followed by SANMs (70.6\%) and ANMs (57.1\%). Nearly half of the ANMs had some knowledge and only $11.8 \%$ SANMs had good knowledge on new born care. Most of the UANMs (93.2\%) had poor knowledge in sign and symptoms of severe infection in newborn followed by $71.4 \%$ ANMs, $70.6 \%$ SANMs and only $11.8 \%$ SANMs had good knowledge.
Table 2. Knowledge on maternal and newborn care among nurse-midwives ( $n=68)$

\begin{tabular}{|c|c|c|}
\hline Knowledge component response & Frequency & $\%$ \\
\hline \multicolumn{3}{|l|}{$\begin{array}{l}\text { Actions taken to prevent/reduce MTCT for } \\
\text { HIV positive women }\end{array}$} \\
\hline $\begin{array}{l}\text { Poor knowledge(less than equal to three in } \\
\text { eight options) }\end{array}$ & 61 & 89.7 \\
\hline $\begin{array}{l}\text { Some knowledge (three to five options in eight } \\
\text { options) }\end{array}$ & 7 & 10.3 \\
\hline \multicolumn{3}{|l|}{$\begin{array}{l}\text { Active Management of III stage of labor and } \\
\text { life saving skills }\end{array}$} \\
\hline $\begin{array}{l}\text { Poor knowledge (less than equal to two in five } \\
\text { options) }\end{array}$ & 26 & 38.3 \\
\hline Some knowledge (three in five options) & 37 & 54.4 \\
\hline Good knowledge(four to five in five options) & 5 & 7.4 \\
\hline \multicolumn{3}{|l|}{ Actions needed on PPH due atonic uterus } \\
\hline $\begin{array}{l}\text { Poor knowledge(less than equal to three in } \\
\text { nine options) }\end{array}$ & 35 & 51.5 \\
\hline Some knowledge (four to six in nine options) & 31 & 45.6 \\
\hline $\begin{array}{l}\text { Good knowledge (seven to nine in nine op- } \\
\text { tions) }\end{array}$ & 2 & 2.9 \\
\hline \multicolumn{3}{|l|}{$\begin{array}{l}\text { Equipment and supplies needed for immedi- } \\
\text { ate newborn care }\end{array}$} \\
\hline $\begin{array}{l}\text { Poor knowledge(less than equal to four in } \\
\text { eleven options) }\end{array}$ & 55 & 80.9 \\
\hline $\begin{array}{l}\text { Some Knowledge(Five to seven in eleven op- } \\
\text { tions) }\end{array}$ & 12 & 17.6 \\
\hline $\begin{array}{l}\text { Good Knowledge(eight to eleven of eleven } \\
\text { options) }\end{array}$ & 1 & 1.5 \\
\hline \multicolumn{3}{|l|}{$\begin{array}{l}\text { Care needed to newborn with no complica- } \\
\text { tion }\end{array}$} \\
\hline $\begin{array}{l}\text { Poor knowledge(less than equal to four in } \\
\text { twelve options) }\end{array}$ & 47 & 69.1 \\
\hline $\begin{array}{l}\text { Some knowledge (five to eight in twelve op- } \\
\text { tions) }\end{array}$ & 19 & 27.9 \\
\hline $\begin{array}{l}\text { Good knowledge (nine to twelve in twelve } \\
\text { options) }\end{array}$ & 2 & 3.0 \\
\hline \multicolumn{3}{|l|}{$\begin{array}{l}\text { Sign and symptoms of severe infection in } \\
\text { newborn }\end{array}$} \\
\hline $\begin{array}{l}\text { Poor knowledge(less than equal to four in } \\
\text { eleven options) }\end{array}$ & 38 & 55.9 \\
\hline $\begin{array}{l}\text { Some Knowledge(Five to seven in eleven op- } \\
\text { tions) }\end{array}$ & 28 & 41.2 \\
\hline $\begin{array}{l}\text { Good Knowledge(eight to eleven of eleven } \\
\text { options) }\end{array}$ & 2 & 3.0 \\
\hline
\end{tabular}

Table 4 presents the knowledge of maternal and newborn care of nursing staffs by their years of working experience. Knowledge in respect to action taken to PMTCT, most of them (91.5\%) had poor knowledge. About $86 \%$ of less than 10 years experienced nursing staffs had poor knowledge, however, majority (61.7\%) of above 10 years of experience nursing staffs had some knowledge on active management of third stage labor and life-saving skills.

Majority (57.4\%) of above 10 years' experience mid-wives had some knowledge compared to $29.8 \%$ among less than 10 years of experience in action needed to heavy bleeding. 
Table 3. Knowledge of maternal and newborn care of nurse-midwives by designations.

\begin{tabular}{|c|c|c|c|c|}
\hline Knowledge components & SANMs 17 & ANMs 7 & UANMs 44 & Total \\
\hline \multicolumn{5}{|l|}{ Actions taken to prevent/reduce MTCT for HIV positive women } \\
\hline Poor knowledge(less than equal to three in eight options) & $82.4 \%$ & $71.4 \%$ & $95.5 \%$ & $89.7 \%$ \\
\hline Some knowledge (three to five options in eight options) & $17.6 \%$ & $28.6 \%$ & $4.5 \%$ & $10.3 \%$ \\
\hline \multicolumn{5}{|l|}{ Active Management of III stage of labor and life saving skills } \\
\hline Poor knowledge (less than equal to two in five options) & $11.8 \%$ & $14.3 \%$ & $52.3 \%$ & $38.2 \%$ \\
\hline Some knowledge (three in five options) & $70.6 \%$ & $57.1 \%$ & $47.7 \%$ & $54.4 \%$ \\
\hline Good knowledge(four to five in five options) & $17.6 \%$ & $28.6 \%$ & $0.0 \%$ & $7.4 \%$ \\
\hline \multicolumn{5}{|l|}{ Actions needed on PPH due atonic uterus } \\
\hline Poor knowledge(less than equal to three in nine options) & $29.4 \%$ & $71.4 \%$ & $56.8 \%$ & $51.5 \%$ \\
\hline Some knowledge (four to six in nine options) & $64.7 \%$ & $14.3 \%$ & $43.2 \%$ & $45.6 \%$ \\
\hline Good knowledge (seven to nine in nine options) & $5.9 \%$ & $14.3 \%$ & $.0 \%$ & $2.9 \%$ \\
\hline \multicolumn{5}{|l|}{ Equipment and supplies needed for immediate newborn care } \\
\hline Poor knowledge(less than equal to four in eleven options) & $70.6 \%$ & $85.7 \%$ & $93.2 \%$ & $86.8 \%$ \\
\hline Some Knowledge(Five to seven in eleven options) & $23.5 \%$ & $14.3 \%$ & $6.8 \%$ & $11.8 \%$ \\
\hline Good Knowledge(eight to eleven of eleven options) & $5.9 \%$ & $0.0 \%$ & $0.0 \%$ & $1.5 \%$ \\
\hline \multicolumn{5}{|l|}{ Care needed to newborn with no complication } \\
\hline Poor knowledge(less than equal to four in twelve options) & $70.6 \%$ & $57.1 \%$ & $90.9 \%$ & $82.4 \%$ \\
\hline Some knowledge (five to eight in twelve options) & $17.6 \%$ & $42.9 \%$ & $9.1 \%$ & $14.7 \%$ \\
\hline Good knowledge (nine to twelve in twelve options) & $11.8 \%$ & $0.0 \%$ & $0.0 \%$ & $2.9 \%$ \\
\hline \multicolumn{5}{|l|}{ Sign and symptoms of severe infection in newborn } \\
\hline Poor knowledge(less than equal to four in eleven options) & $70.6 \%$ & $71.4 \%$ & $93.2 \%$ & $85.3 \%$ \\
\hline Some Knowledge(Five to seven in eleven options) & $17.6 \%$ & $28.6 \%$ & $6.8 \%$ & $11.8 \%$ \\
\hline Good Knowledge(eight to eleven of eleven options) & $11.8 \%$ & $0.0 \%$ & $0.0 \%$ & $2.9 \%$ \\
\hline
\end{tabular}

Most of nursing staffs whether above or less than 10 years of experience had poor knowledge on equipment needed to immediate newborn care and only $19 \%$ and $8.5 \%$ of less than and above 10 years of experience nursing staffs respectively had some knowledge in the same area.

Most of the nursing staffs were found to have poor knowledge on newborn care with no complication regardless the years of experience. Only 19\% and $12.8 \%$ midwives having less than and above 10 years of experience respectively had poor knowledge indicating that higher the experience lowers the knowledge of newborn care. However, only $4.3 \%$ of nursing staffs having more than 10 years of experience had good knowledge on newborn care. Similarly, most of the nursing staffs whether less or above 10 years of experience had poor knowledge with respect to sign and symptoms of severe infection in newborn. Only $4.3 \%$ of nursing staffs having more than 10 years of experience had good knowledge in sign and symptoms of severe infection in newborn. (Table 4)

\section{DISCUSSION}

The purpose of the present study was to provide a quantitative and descriptive analysis of mid-wives in critical knowledge on MCH services in Kapilvastu District, Nepal.

Our study demonstrated that most of the respondents had poor level of knowledge in taking action to prevent/ reduce MTCT for HIV positive women. When compared with designation and experience, UANMs and SANMs were found to have poorer knowledge compared to ANMs, while less than ten years than more than ten years experience nurse-midwives had poor knowledge in taking action to prevent MTCT for HIV positive women. A similar finding was found in a study conducted on Prevention of Mother to Child Transmission of HIV in Nigeria which revealed the poor coverage of the PMTCT program partly as a result of poor knowledge of PMTCT interventions amongst healthcare providers. ${ }^{16}$ However, for effective implementation of РМТСT interventions, upgrading the knowledge of midwives is recommended.

Intra-natal and postnatal cares are important part of obstetrical care. In this regard, a cross sectional survey done in Zimbabwe concluded that both health workers and the community need to have better understanding in the importance of PNC. ${ }^{17}$ Majority of the respondents in this study had some knowledge followed by poor knowledge in performing the active management of third stage of labor and life-saving skills. Similarly, regarding actions needed on PPH due to atonic uterus, more than half of mid-wives had poor knowledge. Some authors found only $15.9 \%$ of obstetric care providers (OCPs) practiced active management of the third stage of labor for all deliveries in Bugesera District, Rwanda. ${ }^{18}$ The mean percentage of 
Table 4. Knowledge of maternal and newborn care among nurse-midwives by years of work experience.

\begin{tabular}{|c|c|c|c|}
\hline \multirow[t]{2}{*}{ Knowledge components } & \multicolumn{2}{|c|}{ Years of experience } & \multirow[t]{2}{*}{ Total } \\
\hline & $<10$ & $>10$ & \\
\hline \multicolumn{4}{|l|}{$\begin{array}{l}\text { Actions taken to prevent/reduce } \\
\text { MTCT for HIV positive women }\end{array}$} \\
\hline $\begin{array}{l}\text { Poor knowledge(less than equal } \\
\text { to three in eight options) }\end{array}$ & $85.7 \%$ & $91.5 \%$ & $89.7 \%$ \\
\hline $\begin{array}{l}\text { Some knowledge (three to five } \\
\text { options in eight options) }\end{array}$ & $14.3 \%$ & $8.5 \%$ & $10.3 \%$ \\
\hline \multicolumn{4}{|l|}{$\begin{array}{l}\text { Active Management of III stage of } \\
\text { labor and life saving skills }\end{array}$} \\
\hline $\begin{array}{l}\text { Poor knowledge (less than equal } \\
\text { to two in five options) }\end{array}$ & $57.1 \%$ & $29.8 \%$ & $38.2 \%$ \\
\hline $\begin{array}{l}\text { Some knowledge (three in five } \\
\text { options) }\end{array}$ & $38.1 \%$ & $61.7 \%$ & $54.4 \%$ \\
\hline $\begin{array}{l}\text { Good knowledge(four to five in } \\
\text { five options) }\end{array}$ & $4.8 \%$ & $8.5 \%$ & $7.4 \%$ \\
\hline \multicolumn{4}{|l|}{$\begin{array}{l}\text { Actions needed on PPH due } \\
\text { atonic uterus }\end{array}$} \\
\hline $\begin{array}{l}\text { Poor knowledge(less than equal } \\
\text { to three in nine options) }\end{array}$ & $76.2 \%$ & $40.4 \%$ & $51.5 \%$ \\
\hline $\begin{array}{l}\text { Some knowledge (four to six in } \\
\text { nine options) }\end{array}$ & $19.0 \%$ & $57.4 \%$ & $45.6 \%$ \\
\hline $\begin{array}{l}\text { Good knowledge (seven to nine } \\
\text { in nine options) }\end{array}$ & $4.8 \%$ & $2.1 \%$ & $2.9 \%$ \\
\hline \multicolumn{4}{|l|}{$\begin{array}{l}\text { Equipment and supplies needed } \\
\text { for immediate newborn care }\end{array}$} \\
\hline $\begin{array}{l}\text { Poor knowledge(less than equal } \\
\text { to four in eleven options) }\end{array}$ & $81.0 \%$ & $89.4 \%$ & $86.8 \%$ \\
\hline $\begin{array}{l}\text { Some Knowledge(Five to seven } \\
\text { in eleven options) }\end{array}$ & $19.0 \%$ & $8.5 \%$ & $11.8 \%$ \\
\hline $\begin{array}{l}\text { Good Knowledge(eight to eleven } \\
\text { of eleven options) }\end{array}$ & $0.0 \%$ & $2.1 \%$ & $1.5 \%$ \\
\hline \multicolumn{4}{|l|}{$\begin{array}{l}\text { Care needed to newborn with } \\
\text { no complication }\end{array}$} \\
\hline $\begin{array}{l}\text { Poor knowledge(less than equal } \\
\text { to four in twelve options) }\end{array}$ & $81.0 \%$ & $83.0 \%$ & $82.4 \%$ \\
\hline $\begin{array}{l}\text { Some knowledge (five to eight in } \\
\text { twelve options) }\end{array}$ & $19.0 \%$ & $12.8 \%$ & $14.7 \%$ \\
\hline $\begin{array}{l}\text { Good knowledge (nine to twelve } \\
\text { in twelve options) }\end{array}$ & $0.0 \%$ & $4.3 \%$ & $2.9 \%$ \\
\hline \multicolumn{4}{|l|}{$\begin{array}{l}\text { Sign and symptoms of severe } \\
\text { infection in newborn }\end{array}$} \\
\hline $\begin{array}{l}\text { Poor knowledge(less than equal } \\
\text { to four in eleven options) }\end{array}$ & $85.7 \%$ & $85.1 \%$ & $85.3 \%$ \\
\hline $\begin{array}{l}\text { Some Knowledge(Five to seven } \\
\text { in eleven options) }\end{array}$ & $14.3 \%$ & $10.6 \%$ & $11.8 \%$ \\
\hline $\begin{array}{l}\text { Good Knowledge(eight to eleven } \\
\text { of eleven options) }\end{array}$ & $0.0 \%$ & $4.3 \%$ & $2.9 \%$ \\
\hline
\end{tabular}

correct answers of 50 questions assessing overall knowledge was $46.4 \%$. Similarly, another study from Tanzania only nine percent out of 106 health care providers made correct statements regarding the all three components of active management of third stage of labor. ${ }^{19}$ Hence, it is suggested that there is a need for improving obstetric knowledge of midwives so that this will lead to better obstetric practices and wellbeing of women and newborn.
This study also revealed that a majority of midwives had poor knowledge in newborn care, equipment and supplies needed for immediate newborn care. About two third of them had poor knowledge on care needed to newborn with no complication and more than half $(55.9 \%)$ had poor knowledge on sign and symptoms of severe infection in newborn. These findings of the study are similar with the study done in Pakistan among Lady Health Workers (LHWs) found that $30 \%$ of them scored more than seventy percent; better score than Medical Officers on issues of maternal and neonatal health. ${ }^{20}$ A similar findings were found in another study done in India which states that knowledge about neonatal resuscitation and some aspects of essential newborn care was poor among health care providers. ${ }^{21}$ Overall performance of maternal and neonatal care was found to be lower among Maternal and Child Health Workers(MCHWs) in previous study done in Nepal. ${ }^{22}$ Due attention should be given to this segment of health workers in increasing knowledge of maternal and newborn care to improve the maternal and child health status in Kapilvastu District, Nepal.

This study is useful for the health programme planners and developmental partners to design intervention effective measures to improve the knowledge of nursemidwives. However, the study has some limitations: first, it was performed only a small area of Kapilvastu district, the findings suffer from generalizability. Second, the true difference in knowledge of nurse-midwives who were recently trained and who were not has not been excluded in this study if this happened. Nonetheless, further study taking a large sample size and considering these limitations in this regard is required.

\section{CONCLUSION}

The assessment of critical knowledge of $\mathrm{MCH}$ among midwives in Kapilvastu District of Nepal revealed that most of the mid-wives had poor and some level of knowledge on most components of maternal and newborn care such as taking action to prevent/reduce MTCT for HIV positive women, equipment and supplies needed for immediate newborn care, actions needed on PPH due to atonic uterus and newborn care. Greater emphasis should be given to upgrade knowledge of maternal and newborn to improve the maternal and child health in concerned district.

\section{ACKNOWLEDGEMENT}

We are grateful to Dr. Nimal Kasturiaratchi, FAIRMED Representative for Nepal for his valuable suggestions in conducting this research and Mr. Karna Bahadur Gurung, Chief, INF, Kapilvastu for his continuous financial support during the research work. We wish to express our thanks to our research assistants Bhagawan Bahadur Karki, Dilip Subedi, Balkrishna Kandel, Kapil Sharma, Yub Raj pandey, Umesh Ghimire as well as the respondents for their active participation in this study. 


\section{REFERENCES}

1. Park's Textbook of Preventive and Social Medicine, $20^{\text {th }}$ ed. $M / S$ BanarsidasBhanot publishers 1167, Premnagar, Jabalpur, 482001 (MP), India; 2009

2. WHO/UNICEF/UNFPA. Maternal mortality in 2000: Estimates developed by WHO, UNICEF and UNFPA. World Health Organization, Geneva; 2004.

3. WHO. The World Health Report: Make Every Mother and Child Count. World Health Organization, Geneva; 2005

4. World Health Organization Proposition of birth attended by a skilled health worker: 2008 updates. World Health Organization, Geneva;2008. p. 16.

5. Government of Nepal: Millennium Development Goals Progress Report 2013. 2013:45-46.

6. Irinnews. The UN Office for the Coordination of Humanitarian Affairs. The conflict's dangerous impact on health services 2005. [Cited 2013 November 14] Available from http://www.irinnews.org/webspecial/ nepal/5 0549.asp.

7. Central Bureau of Statistics, National Planning Commission Secretariate. Nepal Multiple Indicator Cluster Survey, key findings, 2014. Kathmandu: Government of Nepal, National Planning Commission Secretariat \& Central Bureau of Statistics, 2015.

8. Morolong BG, Chabeli MM. Competence of newly qualified registered nurses from a nursing college. Curationis 2005;28(2):38-50.

9. Harvey SA, Ayabaca P, Bucagu M, Djibrina S, Edson WN, Gbangbade $S$, et al. Skilled birth attendant competence: an initial assessment in four countries, and implications for the Safe Motherhood movement. International Journal of Gynecology \& Obstetrics. 2004;87(2):203-10.

10. Oladapo OT, Fawole AO, Loto OM, Adegbola O, Akinola OI, Alao $\mathrm{MO}$, et al. Active management of third stage of labour: a survey of providers' knowledge in southwest Nigeria. Archives of gynecology and obstetrics. 2009;280(6):945-52.

11. Ijadunola KT, ljadunola MY, Esimai OA, Abiona TC. New paradigm old thinking: the case for emergency obstetric care in the prevention of maternal mortality in Nigeria. BMC women's health. 2010;10(1):1.
12. Department of Health Service, Ministry of Health and Population. Annual Report, 2013/2014. Kathmandu, Nepal: Department of Health Services \& Ministry of Health and Population, 2013-2014.

13. Basnett I, Sharma S, Bhusal C, Parajuli R, Anderson K. Increasing access to safe abortion services through auxiliary nurse midwives trained as skilled birth attendants. Kathmandu Univ Med J. 2012;9(4):260-6.

14. Puri M, Tamang A, Shrestha P, Joshi D. The role of auxiliary nursemidwives and community health volunteers in expanding access to medical abortion in rural Nepal. Reproductive health matters. 2015;22(44):94-103.

15. Rai SK, Rai G, Hirai K, Abe A, Ohno Y. The health system in Nepalan introduction. Environmental health and preventive medicine. 2001;6(1):1-8.

16. Nkwo P. Prevention of mother to child transmission of human immunodeficiency virus: the Nigerian perspective. Ann Med Health Sci Res. 2012 Jan;2(1):56-65. doi: 10.4103/2141-9248.96940.

17. Sibanda JQ, Saungweme I, Nleya C, Mutyambizi MP, Rutgers RA. Post natal care in Bubi district deserves more attention. Cent Afr J Med. 2001 Apr;47(4):103-8.

18. Puri R, Rulisa S, Joharifard S, Wilkinson J, Kyamanywa P, Thielman N. Knowledge, attitudes, and practices in safe motherhood care among obstetric providers in Bugesera, Rwanda. International Journal of Gynecology and Obstetrics 2012;116:124-7.

19. Mfinanga GS, Kimaro GD, Ngadaya E, Massawe S, Mtandu R, Shayo $E H$, et al. Health facility-based Active Management of the Third Stage of Labor: findings from a national survey in Tanzania. Health Res Policy Syst. 2009;7(6).

20. Ariff S, Soofi SB, Sadiq K, Feroze AB, Khan S, Jafarey SN et al. Evaluation of health workforce competence in maternal and neonatal issues in public health sector of Pakistan: an Assessment of their training needs. BMC Health Serv Res 2010 Nov 27;10:319. doi: 10.1186/14726963-10-319.

21. Louis D, Kumar P, Gupta A. Knowledge and practices of healthcare providers about essential newborn care and resuscitation in a district of Haryana. J Indian Med Assoc. 2013 Feb;111(2):114-7.

22. Chhetry S, Clapham S, Basnett I. Community based maternal and child health care in Nepal: self-reported performance of Maternal and Child Health Workers. J Nepal Med Assoc. 2005 Jan-Mar;44(157):1-7. 